\title{
Intralenticular metal foreign body: case report
}

\author{
Corpo estranho metálico intracristaliniano:relatodecaso
}

\author{
Flavio Mac Cord Medina ${ }^{1}$ \\ Paulo de Tarso Ponte Pierre Filho ${ }^{2}$ \\ Álvaro Pedroso de Carvalho Lupinacci ${ }^{3}$ \\ Dacio Carvalho Costa ${ }^{4}$ \\ Andréa Mara Simões Torigoe ${ }^{5}$
}

\begin{tabular}{|l|}
\hline ABSTRACT \\
\hline Intralenticular foreign bodies comprise about 5\% to 10\% of all intraocular \\
foreign bodies and can result in serious complications. The management \\
depends on some factors like size, location, material type and the risk of \\
infection. We present a patient with an intralenticular metal foreign body \\
in the left eye that, following initial treatment with topical steroid and \\
antibiotic, underwent lens aspiration with removal of the intralenticular \\
foreign body and insertion of a posterior chamber intraocular lens with \\
good visual outcome.
\end{tabular}

Keyword: Eye foreign bodies; Eye injuries, penetrating; Lens, crystalline/surgery; Lens implantation, intraocular; Case reports [publication type]

\section{INTRODUCTION}

Intraocular foreign bodies (IOFBs) account for approximately $40 \%$ of all penetrating ocular traumas and intralenticular foreign bodies account for approximately $5 \%$ to $10 \%$ of all IOFBs. Such traumas predominate in young $\operatorname{men}^{(1-3)}$. When the lens is injured, capsular integrity has been violated and a visually significant cataract may result. In most cases, the lens becomes sufficiently opaque to require cataract extraction for visual rehabilitation ${ }^{(3-4)}$. In addition, the escape of lenticular proteins and particles may result in glaucoma and severe intraocular inflammation.

The most serious complication of a retained iron-containing IOFB is the development of siderosis bulbi, a sight-threatening complication ${ }^{(5)}$. In most cases of IOFB, early surgical removal of the foreign body is the treatment of choice, especially with recent surgical advances that enable safe removal of the foreign body with good visual results ${ }^{(4)}$.

However, there are reports of such injuries resulting in localized nonprogressive lenticular damage and some physicians have adopted a more conservative approach for the management of these injuries ${ }^{(6-7)}$. We describe a case of a patient treated with lens extraction for removal of a metal intralenticular foreign body.

\section{CASE REPORT}

A 21-year-old healthy man with no past ocular history presented with acute visual loss in the left eye, after hammering iron-containing metal on metal. Upon presentation at the hospital on the same day, his best corrected visual acuity was 20/20 in right eye and 20/40 in left eye. In his left eye, there was a $1 \mathrm{~mm}$ self-sealing corneal laceration temporal to the visual axis, midway between the center of the cornea and the limbus. The anterior chamber was deep with rare inflammatory cells. The corneal wound was self-sealed without any leakage There was a puncture in the anterior capsu- 
le with focal anterior subcapsular opacity and a temporal intralenticular metallic foreign body (Figure 1). Ophthalmoscopy was normal. A B-scan ultrasound in this eye confirmed the presence of a single intralenticular foreign body.

Because the visual function was reduced, the patient received broad-spectrum antibiotics and corticosteroid drops and was elected to undergo combined IOFB removal and lens aspiration with intraocular lens implantation. The foreign body was removed after the capsulorhexis was created, with phacoaspiration of the lens, and removal of the IOFB with a MacPherson forceps and foldable intraocular lens (IOL) implant placed in the capsular bag. The patient has done well postoperatively and his final visual acuity was $20 / 20$ with a minus 1 diopter spherical lens after 6 months of follow-up.

\section{DISCUSSION}

Lens injury is a frequent sequela of trauma involving IOFB. The natural history of lens capsule violation by an IOFB is unclear. The healing capacity of the anterior lens capsule is well documented and is thought to result from the presence of the subcapsular epithelium. If the capsule defect is small, epithelial proliferation rapidly restores its continuity, limiting the free passage of ions and fluid that may result in progressive cataract formation. If the capsular defect is less than $2 \mathrm{~mm}$ it will probably seal by itself. If it is greater than $3 \mathrm{~mm}$, progressive cataract formation will probably occur ${ }^{(8)}$.

The management of intralenticular foreign bodies is controversial $^{(2)}$. In deciding how to manage the traumatized crystalline lens, one should consider patient factors, IOFB characteristics, the location and extent of the lenticular involvement, associated injuries, and procedures to be performed ${ }^{(9-10)}$. The patient's age is particularly important because of the accommodative potential in younger patients. To correct far vision in these patients

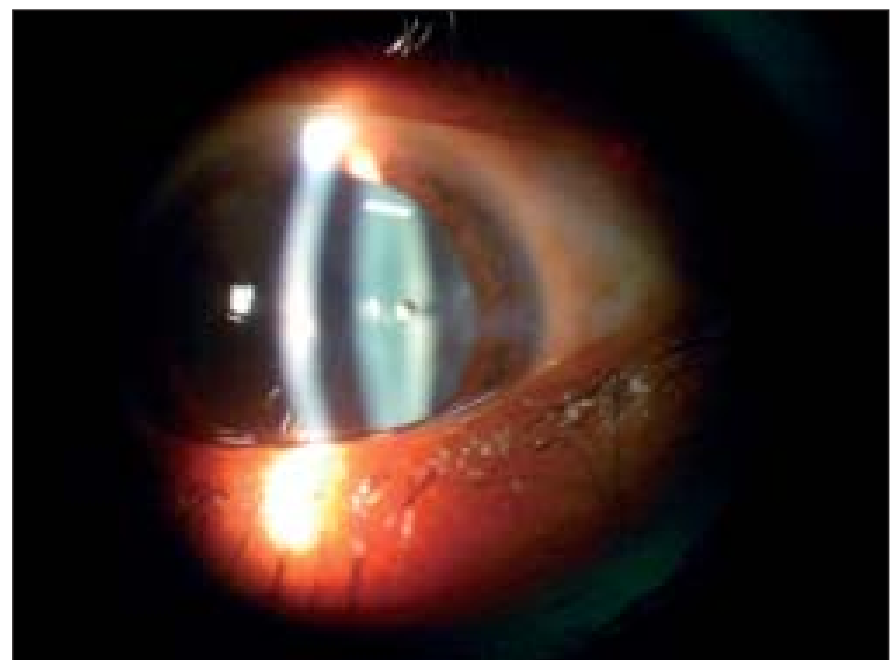

Figure 1 - A slit-lamp photograph of the left eye showing an anterior capsule defect and a metal intralenticular foreign body with an IOL would at best necessitate the use of a corrective lens for near in the involved eye. This subsequent refractive problem in this age group could be disabling ${ }^{(11)}$.

When small, eccentric lens injuries occur, an alternative management is sparing the crystalline lens, removing the foreign body using a magnet or a forceps. However, performing initial lensectomy would save the patient from further surgery $^{(12)}$.

Siderosis bulbi is a sight-threatening complication of a retained iron-containing intraocular foreign body and may occur 18 days to 8 years after ocular injury ${ }^{(4-5)}$. The clinical findings include iris heterochromia, pupillary mydriasis, cataract formation and retinal pigmentary degeneration. Although progression to siderosis bulbi is less likely when the foreign body is localized anterior to the lens than when the foreign body is in the posterior segment, ocular siderosis may occur with an intralenticular foreign body. In case one decides to treat a patient conservatively, he/she should be monitored with serial electroretinograms every 2 to 3 months, with prompt removal of the foreign body should signs of ocular siderosis $\operatorname{occur}^{(7)}$.

The cause of decreased vision in our case was probably due to anterior subcapsular opacity. There were no ocular signs of siderosis bulbi. The decision of performing a onestep procedure was taken because the patient resides far from our hospital facility, and would not be able to come at frequent intervals.

In spite of postoperative inflammation that occurs in most patients, good visual results are possible, as observed in this patient. The use of the appropriate protective eyeglasses in activities with ocular injury risk is extremely important, and should therefore be legally reinforced to minimize serious ocular complications.

\section{RESUMO}

Os corpos estranhos intracristalinianos representam cerca de 5 a $10 \%$ de todos os corpos estranhos intra-oculares. A conduta depende de alguns fatores, como: tamanho, localização, tipo de material e probabilidade de infecção. Relatamos um caso de um paciente com um corpo estranho metálico intracristaliniano no olho esquerdo que, após realizar tratamento inicial com esteróide e antibiótico tópicos, submeteu-se à aspiração do cristalino, retirada do corpo estranho e implante de lente intra-ocular com bom resultado visual.

Descritores: Corpos estranhos no olho; Traumatismos oculares penetrantes; Cristalino/cirurgia; Implante de lente intraocular; Relatos de casos [tipo de publicação]

\section{REFERENCES}

1. Cazabon S, Dabbs TR. Intralenticular metallic foreign body. J Cataract Refract Surg. 2002;28(12):2233-4. 
2. Arora R, Sanga L, Kumar M, Taneja M. Intralenticular foreign bodies: report of eight cases and review of management. Indian J Ophthalmol. 2000;48(2):119-22.

3. Coleman DJ, Lucas BC, Rondeau MJ, Chang S. Management of intralenticular foreign body. Ophthalmology. 1987;94(12):1647-53.

4. Hope-Ross M, Mahon GJ, Johnston PB. Ocular siderosis. Eye. 1993;7(Pt 3): 419-25.

5. O'Duffy D, Salmon JF. Siderosis bulbi resulting from an intralenticular foreign body. Am J Ophthalmol. 1999;127(2):218-9.

6. Keeney AH. Intralenticular foreign bodies. Arch Ophthalmol. 1971;86(5):499-501.

7. Sneed SR, Weingeist TA. Management of siderosis bulbi due to a retained iron-contained intraocular foreign body. Ophthalmology. 1990;97(3):375-9.
8. Fagerholm PP, Philipson BT. Human traumatic cataract. A quantitative microradiographic and electron microscopic study. Acta Ophthalmol (Copenh). 1979; 57(1):20-32.

9. Begle HL. Perforating injuries of the eye by small steel fragments. Am J Ophthalmol. 1929;12(6):970-7.

10. Rychener RO. Siderosis following intralenticular foreign body. Am J Ophthalmol. 1946;29(3):346.

11. Myung JR, Santo RM, Suzuki H, Kara-José N. Corpo estranho intracristaliniano. Rev Bras Oftalmol. 1997;47(2):105-10.

12. O’Neill E, Eagling EM. Intraocular foreign bodies: indications for lensectomy and vitrectomy. Trans Ophthalmol Soc UK. 1978;98(1):47-8. 